\title{
The Effect of Demographic Character on the Intention of Muslim Consumer Behavior to Shop at Neighbor Store
}

\author{
Wandhansari Sekar Jatiningrum *, Amalia Yuli Astuti \\ Industrial Engineering Department, Universitas Ahmad Dahlan, Indonesia \\ Jl. Prof. Dr. Soepomo S.H., Warungboto, Umbulharjo, Yogyakarta, Indonesia \\ * Corresponding author: wandhansari.sekar@ie.uad.ac.id
}

\section{ARTICLE INFO}

Article history

Received October 31, 2018

Revised February 2, 2019

Accepted February 21, 2019

Available Online February 28, 2019

Keywords

Behavioral

Shop

Muslim

Consumer

\begin{abstract}
This study aims to find out factors related to the behavioral intention of Muslim consumers to shop in neighborhood stores. The Islamic leaders urged the Muslim community to do the social movement to buy for neighborhoods. Its movement is as one form of spirit 212. Spirit of the actions of Muslims in Indonesia in December 2016 through prayer and prayer together to strengthen the kinship of Muslims. The behavioral intention of Muslim consumers to shop at a neighborhood store in Yogyakarta is thought to be influenced by attitude, subjective norms, behavioral control, religiousness, and affective commitment to be affiliated with spirit. Consumers have the characteristics of adhering to Islamic principles. Demographic characters are also considered to influence consumer preferences for each factor. In the descriptive analysis, the average respondent's answer to religious factors has the highest score than other factors. In the independent t-tests and ANOVA, the average responses of answers on gender significantly different on education, age, occupation, and income.
\end{abstract}

This is an open-access article under the CC-BY-SA license.

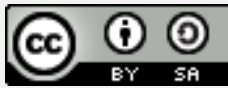

\section{Introduction}

Muslim consumers dominate the number of consumers in Indonesia. It is indicated by the number of Muslims in Indonesia at 87.18\% or ranked first in the world [1]. Muslim consumers primarily drive the economy in Indonesia. However, small traders do not feel much of the economic impact. The trend shows that consumers in Indonesia prefer to shop at supermarkets or modern minimarkets. The community considers supermarkets or minimarkets to have several advantages. These advantages include factors in location, service, variety of goods, and prices [2-4]. It causes small shops owned by Muslims to become increasingly lonely consumers. To minimize the gap between supermarkets and small stalls, Islamic leaders made several appeals. They appealed to Muslim communities to carry out social movements by shopping at the Neighbor Store [5]. 
The movement of shopping in the Neighbor Store is one form of enthusiasm 212. The spirit of 212 results from the Islamic 212 Action 2 December 2016 in Indonesia [6, 7]. This social movement aims to strengthen the economic aspects of the Muslim community. Commitment Muslim communities are expected to encourage the movement of shopping to the Neighbor Store. Muslim consumer behavior has its characteristics. They consider aspects of religion and adhere to Islamic principles. It is different from general consumers $[8,9]$.

In previous research, the enthusiasm of 212 attracted the sympathy of many parties from the country and abroad [7]. Widayat [5] proposed the development of a congregation-based business to revitalize the people's economy. Muslim consumers are encouraged to develop people's economies by shopping. However, in the study, it was not yet known the influence of demographic characters on the shopping intentions of Muslim consumers in the Neighbor Store. Several studies have been conducted to build a Muslim economy. At present, the number of studies is inadequate. Some of these studies have not considered demographic characters. Demographic characters are essential information in supporting marketing strategies and increasing profits. This demographic character includes gender, education, age, type of work, and income. By considering the demographic character, social movements initiated by these scholars can be optimized, and efforts to prosper the people can be achieved. This study aims to find out factors related to the behavioral intention of Muslim consumers to shop in neighborhood stores.

\section{Methods}

\subsection{Hypothesis}

This study attempts to find out the different preferences of respondents for six variables. The variables used in the study include; (1) Affective commitment to affiliation with the spirit of 212. It involvement Muslims to be affiliated with spirit 212. (2) Attitudes. The positive or negative consequences of shopping at the Neighbor Store. (3) Subjective norms. Its perceptions of social pressure to shop at Neighbor Store. (4) Behavior control. It is the individual's perception of the ease or difficulty of shopping at a nearby shop. (5) Religiosity. It is the extent to which Muslims are committed to Islam. (6) Intention Muslim consumers to shop in the Neighbor Store. Muslim consumers intend to shop at the Neighbor Store.

The hypotheses in the study are as follows :

H1: Attitudes, subjective norms, behavioral control, religiosity, affective commitment to affiliation with the spirit of 212, and the intention to shop Muslim consumers in Neighbor Store have significant differences in the gender;

$\mathrm{H} 2$ : Attitudes, subjective norms, behavioral control, religiosity, affective commitment to affiliation with the spirit of 212, and intention to shop Muslim consumers in Neighbor Store have significant differences in the education;

H3: Attitude, subjective norms, behavioral control, religiosity, affective commitment to affiliation with the spirit of 212 , and the intention to shop Muslim consumers in Neighbor Store have significant differences in the age;

H4: Attitudes, subjective norms, behavioral control, religiosity, affective commitment to affiliation with the spirit of 212, and intention to shop Muslim consumers in Neighbor Store have significant differences in Occupation.

H5: Attitudes, subjective norms, behavioral control, religiosity, affective commitment to affiliation with the spirit of 212, and intention to shop Muslim consumers in Neighbor Store have significant differences in income. 


\subsection{Data Collection}

Data collection was done through questionnaires. The sampling technique used purposive sampling. This sampling was chosen to respondents in specific criteria. Research respondents are Muslim individuals who make decisions to buy household needs in Yogyakarta, Indonesia. The number of respondents was 246 people. Data collection is done through questionnaires online and offline.

Questionnaires were made with demographic characters such as gender, education, age, occupation, and income. The research variables used an affective commitment to affiliation with the spirit of 212, attitudes, subjective norms, behavioral control, religiosity, and intention in Muslim consumers to shop at Neighbor Store. The six variables are based on Focus Group Discussion and literature studies from the Jatiningrum and Astuti [6]. Research variables were measured using the Likert scale 1-5. The Likert scale uses the total score of all question items. The analysis is carried out with ANOVA and independent t-test [10-12].

\subsection{Statistical Analysis}

The results were analyzed using an independent t-test and a one-way ANOVA test. The confidence level used is $95 \%$. The t-test is used as a statistical test to compare the mean of 2 groups [13]. Researchers have carried T-Tests, including Mursidi [14, 15], and [16]. Meanwhile, the ANOVA test was used to test the average comparison of more than two groups [13]. This ANOVA test was also carried out by Mursidi [14, 15]. The independent t-test and the one-way ANOVA test were used to test statistically. It indicated the relationship between demographic characters and respondents' preferences towards the research variables.

\section{Result and Discussions}

Table 1 describes the distribution of the demographic characteristics of the respondents. The questionnaire was distributed to 246 respondents. Demographic Characteristics of The Respondents is shown in Table 1. The female respondents dominated the respondents. It is because women play a role in making decisions to buy household needs. Respondents in high school education also dominated the total respondents overall, according to the status of primary students. The age of most respondents is in the age range of 20-29 years. It is in line with survey data from the Central Statistics Agency, written by Wahyuni [17]. She shows that the Indonesian people are primarily in the age of 20-29 years. Most respondents did not fill in their income identities. It is caused by the character of the Indonesian people, who consider income to be sensitive.

Table 2 shows the Ranking of the variable. The religiosity variable was the first position. The Indonesian people were fanatic towards the religion they adhere to [18]. The practical variable commitment to be affiliated with the spirit of 212 occupies the third position. It means that respondents support spirit 212. Nevertheless, respondents tended to indifferent to the result of 212 movements. It was seen in the variable intention to shop, which occupies the last position. An independent t-test was conducted to see the influence of the respondent's gender on the answers given. Table 3 shows the results of the independent t-test. It describes no significant differences between the answers of male and female respondents. The sig $>$ a value indicates this for all variables. Male and female respondents have the same perception related to Muslim consumer behavior. 
Table 1. Demographic Characteristics of the Respondents

\begin{tabular}{|c|c|c|c|}
\hline $\begin{array}{l}\text { Demographic } \\
\text { Character }\end{array}$ & Item & $\begin{array}{l}\text { Number of } \\
\text { Respondents }\end{array}$ & Percentage \\
\hline \multirow[t]{3}{*}{ Gender } & Man & 97 & $39.43 \%$ \\
\hline & Woman & 148 & $60.16 \%$ \\
\hline & Not filled & 1 & $0.41 \%$ \\
\hline \multirow[t]{5}{*}{ Education } & SMA & 151 & $61.38 \%$ \\
\hline & D3 & 20 & $8.13 \%$ \\
\hline & $\mathrm{S} 1$ & 38 & $15.45 \%$ \\
\hline & $\mathrm{S} 2$ & 4 & $1.63 \%$ \\
\hline & Not filled & 33 & $13.41 \%$ \\
\hline \multirow[t]{6}{*}{ Age } & $<20$ years & 31 & $12.60 \%$ \\
\hline & $20-29$ years & 123 & $50.00 \%$ \\
\hline & $30-39$ years & 31 & $12.60 \%$ \\
\hline & $40-49$ years & 25 & $10.16 \%$ \\
\hline & $>49$ years & 24 & $9.76 \%$ \\
\hline & Not Filled & 12 & $4.88 \%$ \\
\hline \multirow[t]{7}{*}{ Occupation } & Student & 96 & $39.02 \%$ \\
\hline & Employee & 46 & $18.70 \%$ \\
\hline & Entrepreneur & 30 & $12.20 \%$ \\
\hline & $\mathrm{CS}$ & 3 & $1.22 \%$ \\
\hline & Housewife & 34 & $13.82 \%$ \\
\hline & Etc. & 21 & $8.54 \%$ \\
\hline & Not Filled & 16 & $6.50 \%$ \\
\hline \multirow[t]{5}{*}{ Income } & $<$ IDR 1million & 71 & $28.86 \%$ \\
\hline & 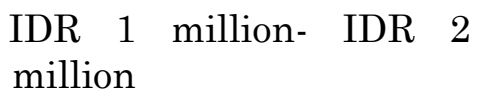 & 48 & $19.51 \%$ \\
\hline & $\begin{array}{l}\text { IDR } 2 \text { million-IDR } 3 \\
\text { million }\end{array}$ & 28 & $11.38 \%$ \\
\hline & >IDR 3million & 18 & $7.32 \%$ \\
\hline & Not Filled & 81 & $32.93 \%$ \\
\hline
\end{tabular}

Table 2. Ranking of each variable

\begin{tabular}{lccccc}
\multicolumn{1}{c}{ Variable } & Mean & Minimum & Maximum & $\begin{array}{c}\text { Standard } \\
\text { Deviation }\end{array}$ & Ranking \\
\hline Religiosity & 4.48 & 3.00 & 5.00 & 0.43 & 1 \\
Attitude & 4.00 & 2.50 & 5.00 & 0.57 & 2 \\
Behavior Control & 3.85 & 2.67 & 5.00 & 0.58 & 3 \\
Affective commitment & 3.72 & 2.40 & 5.00 & 0.59 & 4 \\
to affiliation with & & & & & \\
Spirit 212 & & & & 0.60 & 5 \\
Subjective Norms & 3.60 & 2.00 & 5.00 & 0.48 & 6 \\
Intention to shop at & 3.42 & 2.29 & 5.00 & & \\
Neighbor Store & & & & & \\
\hline
\end{tabular}

A one-way ANOVA test was conducted to see the effect of education, age, occupation, and income on the respondents' answers. Table 4 describes the ANOVA test for education. Respondents were grouped into SMA, D3, S1, and S2. The ANOVA test 
results showed that respondents' answers to religiosity variables differed significantly between education groups. After a post hoc test, answers were significantly different between respondents with high school education with S1 and SMA with S2. The religiosity of respondents with S1 and S2 education tends to be higher than respondents' religiosity with high school education. Centre [19] states that the higher the level of public education in America, the lower religiosity.

Table 3. Independent t-test for gender demographic factors

\begin{tabular}{|c|c|c|c|c|c|c|}
\hline \multirow{2}{*}{ Variable } & \multicolumn{2}{|c|}{ Man } & \multicolumn{2}{|c|}{ Woman } & \multirow{2}{*}{$\begin{array}{c}\text { t- } \\
\text { value }\end{array}$} & \multirow{2}{*}{ Sig. } \\
\hline & Mean & S.D & Mean & S.D & & \\
\hline $\begin{array}{l}\text { Affective commitment to } \\
\text { affiliation with Spirit } \\
212\end{array}$ & 3.75 & 0.55 & 3.7 & 0.62 & 0.62 & 0.53 \\
\hline Attitude & 3.98 & 0.61 & 4.02 & 0.55 & -0.47 & 0.63 \\
\hline Subjective Norms & 3.55 & 0.57 & 3.64 & 0.62 & -1.19 & 0.23 \\
\hline Behavior Control & 3.82 & 0.57 & 3.86 & 0.58 & -0.48 & 0.63 \\
\hline Religiosity & 4.47 & 0.4 & 4.48 & 0.45 & -0.197 & 0.3 \\
\hline $\begin{array}{l}\text { Intention to shop at } \\
\text { Neighbor Store }\end{array}$ & 3.38 & 0.46 & 3.45 & 0.5 & -1.039 & 0.3 \\
\hline
\end{tabular}

Table 4. ANOVA test for education

\begin{tabular}{|c|c|c|c|c|c|c|}
\hline Variable & $\begin{array}{c}\text { Mean score } \\
\text { for SMA }\end{array}$ & $\begin{array}{l}\text { Mean } \\
\text { score for } \\
\text { D3 }\end{array}$ & $\begin{array}{l}\text { Mean } \\
\text { score for } \\
\text { S1 }\end{array}$ & $\begin{array}{l}\text { Mean } \\
\text { score for } \\
\text { S2 }\end{array}$ & $\mathrm{F}$ & Sig. \\
\hline $\begin{array}{l}\text { Affective } \\
\text { commitment } \\
\text { affiliation } \\
\text { Spirit } 212\end{array}$ & 3.68 & 3.82 & 3.88 & 4 & 1.63 & 0.18 \\
\hline Attitude & 3.97 & 3.99 & 4.1 & 4.3 & 0.81 & 0.49 \\
\hline Subjective Norms & 3.56 & 3.49 & 3.74 & 3.95 & 1.51 & 0.21 \\
\hline Behavior Control & 3.88 & 3.78 & 3.84 & 3.75 & 0.23 & 0.88 \\
\hline Religiosity & 4.45 & 4.56 & 4.61 & 4.92 & $2.95^{*}$ & $0.03^{*}$ \\
\hline $\begin{array}{l}\text { Intention to shop at } \\
\text { Neighbor Store }\end{array}$ & 3.37 & 3.48 & 3.52 & 3.68 & 1.62 & 0.18 \\
\hline
\end{tabular}

Table 5 shows the results of the one-way ANOVA test for age. It was grouped into $<20$ years, 20-29 years, 30-39 years, 40-49 years, and $>49$ years. Respondents' answers or preferences to the variables of affective commitment, attitudes, subjective norms, and intention to shop at the Neighbor Store differ significantly in each age group. Respondents with age $<20$ years have characteristics of affective commitment that are significantly different from respondents aged 40-49 years and $>49$ years. Likewise, respondents aged 20-29 years with respondents aged 40-49 years and $>49$ years. Older respondents have a higher emotional involvement to be affiliated with spirit 212. It is demonstrated through the many Islamic leaders involved in the Islamic Defendation Act 212, older people.

The respondents' attitudes differed significantly in the age group $<20$ years with 40-49 years and 20-29 years with $40-49$ years and $>49$ years. The higher the respondent's age, the higher the level of confidence in the positive consequences of shopping at the Neighbor Store. Significant subjective norm differences occur in the age group 20-29 years with 40-49 years. This difference also occurs in the age group $>49$ years and the $30-39$ year 
age group with 40-49 years and $>49$ years. Respondents with a higher age tend to feel the surrounding environment supports their behavior to shop at Neighbor Store. Likewise, in the variable intention to shop in Neighbor Store, respondents with age $>49$ years tend to have higher intentions. For this reason, an approach to young people is needed so that the whole movement of the people can be realized, especially the shopping social movement to the Neighbor Store.

Table 5. ANOVA Test for Age

\begin{tabular}{|c|c|c|c|c|c|c|c|}
\hline Variable & $\begin{array}{c}\text { Mean } \\
\text { score } \\
\text { for }<20 \\
\text { years }\end{array}$ & $\begin{array}{c}\text { Mean } \\
\text { score } \\
\text { for } 20- \\
29 \\
\text { years }\end{array}$ & $\begin{array}{c}\text { Mean } \\
\text { score } \\
\text { for } 30- \\
39 \\
\text { years }\end{array}$ & $\begin{array}{c}\text { Mean } \\
\text { score } \\
\text { for } 49- \\
\quad 49 \\
\text { years }\end{array}$ & $\begin{array}{l}\text { Mean } \\
\text { score for } \\
>49 \\
\text { years }\end{array}$ & $\mathrm{F}$ & Sig. \\
\hline $\begin{array}{l}\text { Affective } \\
\text { commitment to } \\
\text { affiliation with } \\
\text { Spirit } 212\end{array}$ & 3.63 & 3.61 & 3.8 & 3.98 & 3.99 & 3.91 & $0.04^{*}$ \\
\hline Attitude & 3.97 & 3.92 & 4.02 & 4.31 & 4.19 & 3.12 & $0.02 *$ \\
\hline Subjective Norms & 3.6 & 3.52 & 3.5 & 3.85 & 3.87 & 3.01 & $0.019^{*}$ \\
\hline Behavior Control & 3.82 & 3.83 & 3.85 & 4.01 & 4.00 & 0.92 & 0.45 \\
\hline Religiosity & 4.47 & 4.43 & 4.57 & 4.57 & 4.55 & 1.22 & 0.31 \\
\hline $\begin{array}{l}\text { Intention to shop } \\
\text { at Neighbor Store }\end{array}$ & 3.42 & 3.33 & 3.44 & 3.6 & 3.69 & 4.02 & $0.004^{*}$ \\
\hline
\end{tabular}

Table 6 shows the results of the ANOVA test. The respondents' work is grouped into students, the private sector, Civil Servants (CS), Housewives (HS), and others. The ANOVA test results showed a significant difference in behavioral control variables, religiosity, and intention to shop at Neighbor Store in each workgroup. For behavioral control variables, significant differences occurred in the occupational group of students with self-employment and private employee employment groups. Significant differences also occur in groups of entrepreneurs, civil servants, and HS with other workgroups. The average respondent with the smallest score was in the other workgroups. CS workgroup had the highest average answer. It means that respondents with workgroups of civil servants have perceptions tend to be comfortable and very easy to buy products in Neighbor Store.

A significant difference occurred in the respondent's answer to the student workgroup with the HS in the religiosity variable. This difference also occurs in private employees working with entrepreneurs, civil servants, and HSs with others. In the respondents' average answers, students have a lower level of religiosity than civil servants, HSs, private employees, and others. It shows that the higher the individual's age, the higher the level of religiosity [20]. Increasing student religiosity can be done by creating and cultivating religious values in schools. For the variable intention to shop in the Neighbor Store, all workgroups have significantly different answers. The highest average score of respondents' answers to this variable is in the CS workgroup. It shows that respondents agreed to have the intention to shop at Neighbor Store. Respondents with other workgroups gave a rating that tended to be neutral to have the intention to shop at Neighbor Store. It shows that the appeal of the socio-economic movement of the people for the Ummah is still not entirely successful. 
Table 6. ANOVA Test for Occupation

\begin{tabular}{|c|c|c|c|c|c|c|c|c|}
\hline Variable & $\begin{array}{l}\text { Mean } \\
\text { score for } \\
\text { Student }\end{array}$ & $\begin{array}{l}\text { Mean } \\
\text { score for } \\
\text { Employee }\end{array}$ & $\begin{array}{l}\text { Mean score } \\
\text { for the } \\
\text { entrepreneur }\end{array}$ & $\begin{array}{l}\text { Mean } \\
\text { score } \\
\text { for CS }\end{array}$ & $\begin{array}{l}\text { Mean } \\
\text { score for } \\
\text { HS }\end{array}$ & $\begin{array}{l}\text { Mean } \\
\text { score for } \\
\text { Etc. }\end{array}$ & $\mathrm{F}$ & Sig. \\
\hline $\begin{array}{l}\text { Affective } \\
\text { commitment to } \\
\text { affiliation with } \\
\text { Spirit } 212\end{array}$ & 3.66 & 3.7 & 3.77 & 4.33 & 3.78 & 3.79 & 1.04 & 0.4 \\
\hline Attitude & 3.94 & 3.99 & 4.13 & 4.58 & 4.13 & 3.77 & 2.21 & 0.054 \\
\hline $\begin{array}{l}\text { Subjective } \\
\text { Norms }\end{array}$ & 3.5 & 3.63 & 3.75 & 4.13 & 3.63 & 3.47 & 1.64 & 0.15 \\
\hline $\begin{array}{l}\text { Behavior } \\
\text { Control }\end{array}$ & 3.77 & 3.87 & 4.07 & 4.33 & 3.88 & 3.55 & $2.81^{*}$ & $0.02^{*}$ \\
\hline Religiosity & 4.46 & 4.57 & 4.35 & 4.78 & 4.62 & 4.28 & $3.08^{*}$ & $0.01 *$ \\
\hline $\begin{array}{l}\text { Intention to } \\
\text { shop at } \\
\text { Neighbor Store }\end{array}$ & 3.33 & 3.34 & 3.57 & 4.00 & 3.57 & 3.26 & $3.93^{*}$ & $0.00^{*}$ \\
\hline
\end{tabular}

Table 7 shows the results of testing with income demographic characters. Respondents were grouped by income group < IDR 1 million, IDR 1 million - IDR 2 million, IDR 2 million- IDR 3 million, and> IDR 3 million. Significant differences in the answers or preferences of respondents occur in the variables of affective commitment, attitudes, subjective norms, and intention to shop at Neighbor Store. Respondents' answers to the four variables differed significantly in income groups $<1$ million, 1-2million, 2-3 million with income groups $>3$ million. Respondents in the income group $>3$ million tended to provide answers with high scores on all four variables. It shows that in the most critical income group, the average respondent already has emotional involvement to affiliate with spirit 212. The group also has confidence in the positive consequences of shopping at a Neighbor Store. In addition, respondents get influence and have the intention to shop at Neighbor Store. High-income respondents, on average, have high social care behaviors as well.

Table 7. ANOVA Test for Income

\begin{tabular}{|c|c|c|c|c|c|c|}
\hline Variable & $\begin{array}{c}\text { Mean score } \\
\text { for }<1 \\
\text { million }\end{array}$ & $\begin{array}{l}\text { Mean score } \\
\text { for } 1-2 \\
\text { million }\end{array}$ & $\begin{array}{l}\text { Mean score } \\
\text { for } 2-3 \\
\text { million }\end{array}$ & $\begin{array}{c}\text { Mean score } \\
\text { for }>3 \\
\text { million }\end{array}$ & $\mathrm{F}$ & Sig. \\
\hline $\begin{array}{l}\text { Affective } \\
\text { commitment to } \\
\text { affiliation with } \\
\text { Spirit } 212\end{array}$ & 3.65 & 3.58 & 3.72 & 4.41 & 10.61 & $0.00^{*}$ \\
\hline Attitude & 3.96 & 4.04 & 3.85 & 4.49 & 5.16 & $0.002^{*}$ \\
\hline Subjective Norms & 3.51 & 3.6 & 3.55 & 4.04 & 3.62 & $0.014^{*}$ \\
\hline Behavior Control & 3.84 & 3.98 & 3.84 & 4.00 & 0.72 & 0.54 \\
\hline Religiosity & 4.46 & 4.45 & 4.43 & 4.75 & 2.41 & 0.07 \\
\hline $\begin{array}{l}\text { Intention to shop } \\
\text { at Neighbor Store }\end{array}$ & 3.31 & 3.45 & 3.44 & 3.78 & 4.99 & $0.002^{*}$ \\
\hline
\end{tabular}

Table 8 shows the recapitulation of the independent $t$-test and the one-way ANOVA test for each variable in each demographic characteristic. It shows no significant differences in respondent's answers. In the respondents' education, the ANOVA test 
results showed that the average response or preference of respondents differed significantly on the variable religiosity. In age, it was found that respondents' preferences differed significantly in the variables of behavior control, religiosity, and intention to shop at Neighbor Store. Income describes a significant difference in the average answers to affective commitment variables affiliated with spirit 212 . These differences also occur in attitude variables, subjective norms, and intention to shop at Neighbor Store.

Table 8. Recapitulation of the results of the independent $t$-test and one-way ANOVA

\begin{tabular}{|c|c|c|c|c|c|c|}
\hline \multirow[b]{2}{*}{$\begin{array}{l}\text { Demographic } \\
\text { Character }\end{array}$} & \multicolumn{6}{|c|}{ Variable } \\
\hline & $\begin{array}{l}\text { Affective } \\
\text { commitment to } \\
\text { affiliation with } \\
\text { Spirit } 212\end{array}$ & $\begin{array}{c}\text { Attitu } \\
\text { de }\end{array}$ & $\begin{array}{l}\text { Subjectiv } \\
\text { e Norms }\end{array}$ & $\begin{array}{c}\text { Behavior } \\
\text { Control }\end{array}$ & Religiosity & $\begin{array}{l}\text { Intention to } \\
\text { shop at } \\
\text { Neighbor } \\
\text { Store }\end{array}$ \\
\hline Gender & 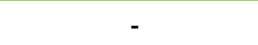 & - & - & - & - & - \\
\hline Education & - & - & - & - & V & - \\
\hline Age & V & V & V & - & - & V \\
\hline Occupation & & & & V & $\mathrm{V}$ & V \\
\hline Income & V & V & V & - & - & V \\
\hline
\end{tabular}

\section{Conclusion}

In the descriptive analysis of the respondent's answer, the religiosity variable shows that the religiosity of the Indonesian Muslim community was relatively high. The results of the t-test show that the average answers for male and female respondents no significant differences. At the same time, the ANOVA test results showed that the average respondent's answer education only differed significantly on the variable religiosity. For other demographic characters, such as age, occupation, and income, the respondents' answers differ significantly on most variables. The strategy for a holistic movement of the people can be done by understanding the demographic character of Muslims. Future research can be done by adding other demographic characters such as ethnic groups. Further research can also be done in various other regions in Indonesia because each region has different consumer characteristics.

\section{Acknowledgment}

The author would like to thank the Ministry of Research, Technology, and Higher Education for funding this research. This research was funded through the Beginner Lecturer Research scheme, which passed funding in 2018.

\section{References}

[1] A. Na'im and H. Syaputra, Kewarganegaraan, suku Bangsa, agama, dan bahasa sehari-hari penduduk Indonesia: Hasil Sensus Penduduk 2010. Jakarta: Badan Pusat Statistik (BPS), 2011.

[2] T. Aryanti, "Analisis Perilaku Konsumen Dalam Pemilihan Tempat Belanja Dengan Pendekatan Analytical Hierarchy Process (Studi Kasus Pada Masyarakat Di Kota Depok)," Universitas Gunadarma, Jakarta, 2012.

[3] G. T. Hariyadi, "Faktor-Faktor Yang Mempengaruhi Konsumen Berbelanja Di Minimarket (Studi pada Indomaret dan Alfamart di Semarang)," 2017, vol. 1, 2017. https://doi.org/10.33633/jpeb.v1i1.1475. 
[4] S. Sunanto, "Modern retail impact on store preference and traditional Retailers in West Java," Asian Journal of Business Research, vol. 2, pp. 1-19, 2012. https://ssrn.com/abstract=2345170.

[5] P. Widayat, "Pemberdayaan Ekonomi Umat dengan Pengembangan Usaha "Kita Mart" Yang Berbasis Jamaah," Jurnal Diklat Review, vol. 1, pp. 172-175, 2017. http://ejournal.kompetif.com/index.php/diklatreview/article/view/172.

[6] W. Jatiningrum and A. Astuti, "Theorizing of spirit 212 in predicting Muslim behavioral intentions: A hypothesized model," in IOP Conference Series: Materials Science and Engineering, 2018, p. 012047. https://doi.org/10.1088/1757899X/403/1/012047.

[7] A. S. Pamungkas and G. Octaviani, "Aksi bela islam dan ruang publik muslim: dari representasi daring ke komunitas luring," Jurnal Pemikiran Sosiologi, vol. 4, pp. 65-87, 2017. https://doi.org/10.22146/jps.v4i2.28581.

[8] M. Hamid, "Islamic economics: An introductory analysis," Englishversion, firstedition, pp. 142-144, 2009.

[9] B. Hossain, "Application of Islamic Consumer Theory: An Empirical Analysis in the Context of Bangladesh," Global Review of Islamic Economics and Business, vol. 2, pp. 069-083, 2015. https://doi.org/10.14421/grieb.2014.021-05.

[10] H. N. Boone and D. A. Boone, "Analyzing likert data," Journal of extension, vol. 50, pp. 1-5, 2012. https://www.joe.org/joe/2012april/tt2.php.

[11] W. Budiaji, "Skala pengukuran dan jumlah respon skala likert," Jurnal Ilmu Pertanian dan Perikanan, vol. 2, pp. 127-133, 2013.

[12] J. Carifio and R. J. Perla, "Ten common misunderstandings, misconceptions, persistent myths and urban legends about Likert scales and Likert response formats and their antidotes," Journal of Social Sciences, vol. 3, pp. 106-116, 2007.

[13] D. C. Montgomery, "Design and Analysis of Experiments, Eight Ed.," A. J. W. Sons, Ed., ed: Inc, 2013.

[14] M. Mursidi, "Pengaruh Pendidikan dan Pelatihan Terhadap Kinerja Karyawan Universitas," Jurnal Teknik Industri, vol. 10, p. 8, 2012. https://doi.org/10.22219/JTIUMM.Vol10.No2.120-127.

[15] M. Mursidi, "Variabel-Variabel yang Mempengaruhi Keputusan Konsumen Menginap Di University Inn Umm," 2012, vol. 11, p. 7, 2012. https://doi.org/10.22219/JTIUMM.Vol11.No1.56-62.

[16] H. M. Kholik and D. A. Krishna, "Analisis Tingkat Kebisingan Peralatan Produksi Terhadap Kinerja Karyawan," 2012, vol. 13, p. 7, 2012. https://doi.org/10.22219/JTIUMM.Vol13.No2.194-200.

[17] S. Wahyuni. Umur dan Jenis Kelamin Penduduk Indonesia Hasil Sensus Penduduk 2010 [Online].

[18] A. M. Mulkhan, "Humanisasi pendidikan islam," Tashwirul Afkar, vol. 11, pp. 1725, 2001.

[19] P. R. Centre, "In America, Does More Education Equal Less Religion?," ed, 2017.

[20] V. L. Bengtson, M. Silverstein, N. M. Putney, and S. C. Harris, "Does religiousness increase with Age? Age changes and generational differences over 35 Years," Journal for the Scientific Study of Religion, vol. 54, pp. 363-379, 2015. https://doi.org/10.1111/jssr.12183. 